Témoigner

Getuigen
Témoigner. Entre histoire et mémoire

Revue pluridisciplinaire de la Fondation Auschwitz

125 | 2017

Histoire et mémoire de la persécution des

homosexuel-le's par les nazis

\title{
Collectief geheugen en didactiek: Los años del terror (50 preguntas sobre el conflicto armado en Peru, 1980-2000) van Jesús Cossío
}

Vers une pédagogie de la mémoire collective. Los años del terror (50 preguntas

sobre el conflicto armado en peru, 1980-2000), Jesús Cossío

\section{Mylène Herry}

Traducteur : Gorik de Henau

\section{(2) OpenEdition}

\section{Journals}

Édition électronique

URL : https://journals.openedition.org/temoigner/6740

DOI : $10.4000 /$ temoigner. 6740

ISSN : 2506-6390

Cet article est une traduction de :

Vers une pédagogie de la mémoire collective - URL : https://journals.openedition.org/temoigner/6717 $[\mathrm{fr}]$

Éditeur :

Éditions du Centre d'études et de documentation Mémoire d'Auschwitz, Éditions Kimé

Édition imprimée

Date de publication : 1 octobre 2017

Pagination : 150-158

ISBN : 978-2-930953-01-4

ISSN : 2031-4183

Référence électronique

Mylène Herry, «Collectief geheugen en didactiek: Los años del terror (50 preguntas sobre el conflicto armado en Peru, 1980-2000) van Jesús Cossío», Témoigner. Entre histoire et mémoire [Online], 125 | 2017, Online op 24 décembre 2021, geraadpleegd op 03 février 2022. URL: http://journals.openedition.org/ temoigner/6740 ; DOI: https://doi.org/10.4000/temoigner.6740 


\section{COLLECTIEF GEHEUGEN EN DIDACTIEK:}

$\diamond$ Deze rubriek wil inzicht bieden in de soms problematische processen van herinne-
ringsconstructie overal ter wereld. In plaats van te focussen op gebeurtenissen zelf, onderzoeken auteurs in het Herinneringslab hoe een collectieve herinnering ontstaat en wordt gecultiveerd, en bestuderen ze de sociopolitieke gevolgen werk in een bepaald regio.

Los años del terror is een recent boek (2016) van Jesús Cossío, een Peruaans striptekenaar die het bij voorkeurheeft over het interne conflict in zijnland in dejaren tachtigen negentig. Hij is de auteur van twee albums, Rupay (2008) en Barbarie (2010), waarin hij op grafische wiszes Peruart tussen de F. AA (Fusas Armadas/het (Partido Coger), de rebur (Partido Comunista del Perá-Sendero Luminoso/ Perta (Movido en Revolu (Movion Revolutionaire Beweging Túpac Amaru), en/o paramilitaire organisaties. Die episodes werden uitvoerig onderzocht tijdens de werkzaamheden van de CVR (Comisión dela Verdady Reconciliación/
Waarheids- en Verzoeningscommissie).
LOS AÑOS DEL TERROR (50 PREGUNTAS SOBRE EL CONFLICTO ARMADO EN PERU, 1980-2000) VAN JESÚS COSSÍO

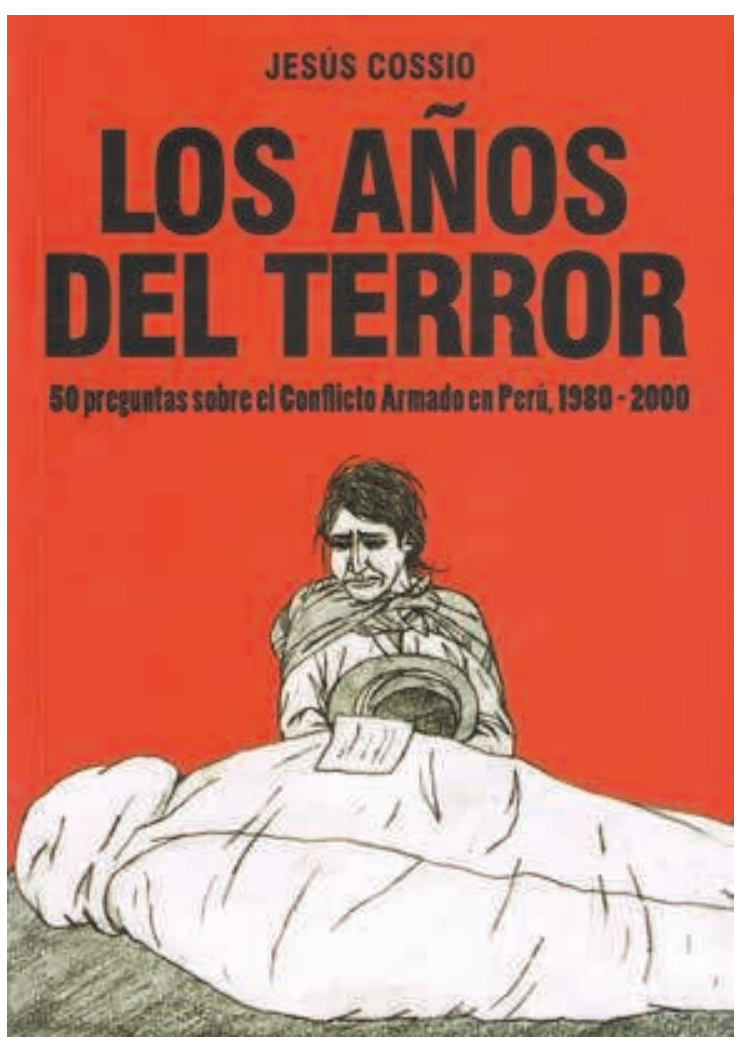

woordvorm met grafische legenden, waardoor de geschiedenis van het land voor educatieve, ethische en Viiftien jsdoeleinden een didactische structuur krijgt. de jonge generaties over de terreurjare de jonge generaties over de terreurjaren aan de han zo Zoals Tahar Ben Jelloun eerder deed in zijn werken op historisch-wotisne en p historisch-wetenschappelijke bewijzen en docuen dire prenten, de ene vanvoudigweg nast de and cere prenten, de nee invere de antworder is belon rijk de feiten te blijven toelichten. Wanthet is belangrijk de feiten te blijven toelichten, uitleggen, tonen, analyseren en bekritiseren in een land waar nog levendige discussies worden gevoerd over wie de verantwoordeljkhid dramot, over de justheid van de kenning van het verleden.

VORMELIJKE EN PEDAGOGISCHE AANPAK VAN HET TOOLBOEK

n deze werken ${ }^{1}$ stelt Cossío beeldend, met tekeningen, foto's en kaarten, de gewelddaden van het lege ling die de boeren in de Andes te bert viel, wand ling die de bouren in de Andes te beurt viel, want zij waren meestal het slachtoffer van deze geweldgolf. wor inarich maning tiek tiek engagement en de moeizame toepassing van de . Det verslag werd bekendgenaakt.

het is een instru, tenissen op twee verschillende manieren tracht uit te oog la merde delen verbindt hij teksten.

(1) Als bijlage zit bij het werk ook een fragment uit Barbarie: twee gewelddadige episodes betreffende de slachtpartij in Accomarca
(augustus 1985 ) en de moordpartijen in Aranhuuay en Pacchas
(april 1988 - december 1989).
In een eerste deel wil ik het hebben over de pedagogische keuzes van de auteur. In hoeverre heeft de gogische kenzes van de auteur. In hoeverre heett de clemen de deor doorgeven wan de herinnering? Vervolgens zal ik nis te laten preken. Hoe brengt Los anos del tedor de CVR-getigen. de CVR-getuigenissen? In laatste instantie zal ik me ductieve dine hij te teve dimensie van de tragedie belicht. Hoe gaat hister problenatiek en hen aan te sporen de fouten van het

Zoals de ondertitel aangeeft, stelt de auteur vijftig Het werk kent geen pagik (2) Ik denk daarbij aan de trilogie: Papa, wat is een vreemdeling?,
Papa, wat is een moslim? (2012) en Le terrorisme expliqué à nos enfants
[niet vertaald]. die hij vervolsens duidelijk en precies be (1980-2000) 
. van de vragen dienen als aanknopingspunt. De vragen kunnen worden 'onderverdeeld' in verschillende categorieën, al naargelanghet beoogde kennisniveau van c 作 . nieerd, bovendien is achter in het boek ook nog een

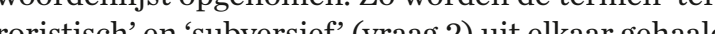

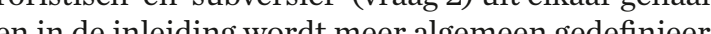
wa (hetbin (het binnenlandsegewapend Jonict, naag1).Kweste van de woorden doordacht te gebruken on te weten cer wat en we coord w te.

De auteur heeft het ook vaak over de levensloop van de protagonisten van het conflict: hij wijst op verw PCP-SL (val 3 ), Ze MRTA (vrag 21), de Col over de (vr-S (vang (26). leger spe le en watvoorewe ger speen wat voorgeneld politiek-histoische aan jzingen word ech mink een minimale feitelijke context, die een goed begrip anint methet definiëren van hetbinak. Hetboek

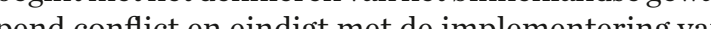
pend confict en eindigt met de implementering van cha verhaal komen de presidentièle ambtstermijnen aan bod, end veranderingen en problemen (overwinnin(1992) van Abin Zo gat Guzman, de aanvoerdervan de PCP-SL, tijdens het pre

Met zijn vragen tracht de auteur een objectief, delijkeden, warbij hij tegelijkindividuele schantwoortipt. In twee vagen $(37,38)$ gat stipt. In twee vragen $(37,38)$ gaat het bijvoorbeeld ove gebeurtenisseningevangenissen: enerzijds de opstand Lima misbruiken werd aangekeken, onder meer marteling in kazernes en detentiecentra. In beide gevallen wijzen de het leger the Uit de dieper liggend onrecht en een sociale halaise. Uit de nadrukkelijke wijze waarop de auteu me Totson.

Then warmee id eventuele wilbekijken Zo bom hij in vrag 20 terug op de redewen warom veel Perij in vaag 20 terng op de redewhe proble problem van de dubbele reptie van het CVR-eindanderen sonn misprijzen

De antwoorden zijn kort en bondig, gemiddeld tien regels. Ze omvatten een mengeling van officiële, fictieve, visuele en anekdotische uitingen en op die vin via gestaafde 'kleine verhalen. De nadruk komt te ligde lep het vinger zich kan identificeren. De grafische vormgeving dient als legende bij deverkarende tekst engeef Ikzathet

. verdediging in vés (CAD/Comités de autode zent) verdedigngsonités (CAD/Comités de autodefensa), we bat lie laste term in he dat die laatsteterm in de Andes al eer vee tegen diefstal bewakten. In de context han of vee tegen diefstal bewaakten. In de context van het 'ronnas' min of meer 'rondas' min of meer georganiseerd waren en dat ze soms banden onderhielden met de F.AA on samen te vechten tegen opkomende subversieve groepen. De heralng einde van het antwoord onderstreepthetbelang ervan in het binnenlandse contict. Onder de paragraal staat een strook we zien dian strook. We zien een dialoog tussen twee Andesboeren, waruit hum motivatie blijht om de PCP-SL tegen te
18. QQué papel curnpiersen las randas patu Luntener a Serdero Lumi
noso?

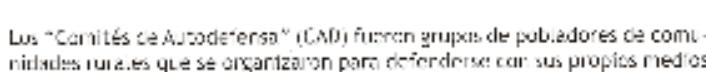

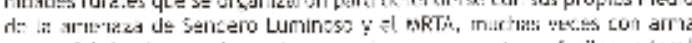

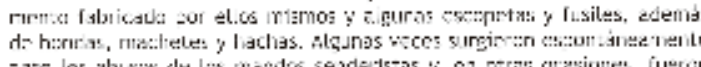

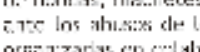

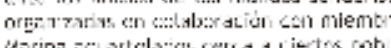

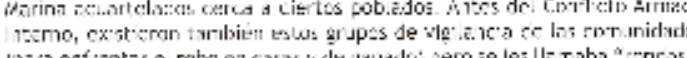

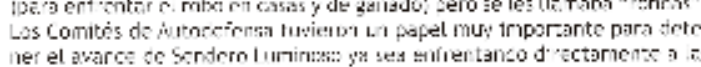

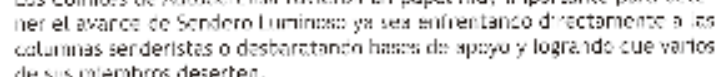

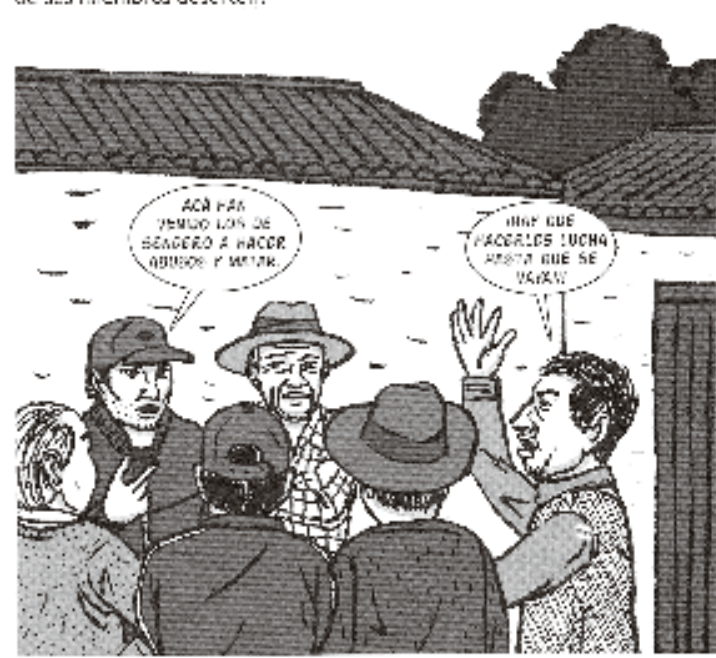

houden. Op de rugzijde van deze eerste reeks antwoorden zien we een grafische weergave van de ambachtelijke wapens van deze zelfverdedigingsgroepen, die in de antwoordtekst worden opgesomd. Tekeningen van it het CVR - eindverslag dat het derde ond ang citaat the hor het antwoord vormt. Daarin wordt verslag uitgebrach de Valle de los Ríos rrivierenvallei] Apurímacucho, in in Junín. los Ror de [riverente tekt op te nemen Ene, in Junin. Door de officiele tekst op te nemen kan de auteur deverkaringen funderen enverantwoorden. De benon flict: na het uitbreken van de vijandelijkheden waren

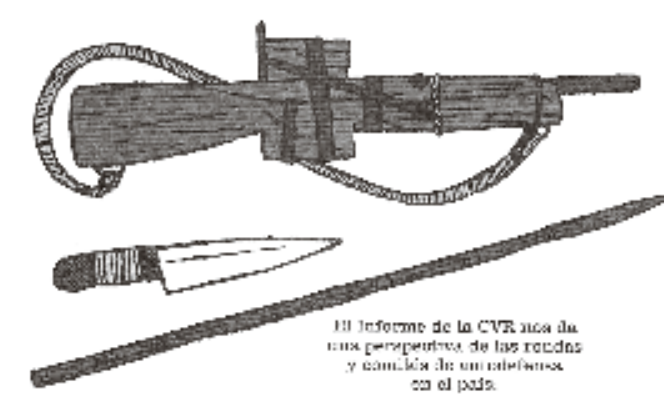

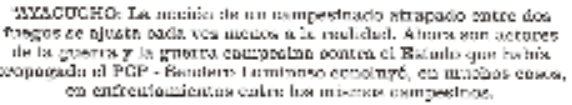

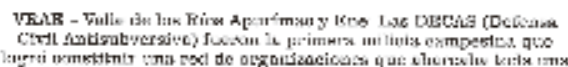

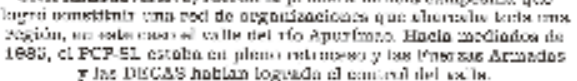

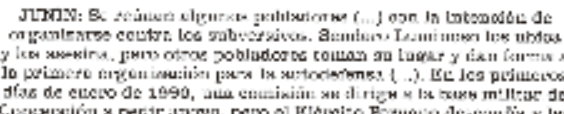

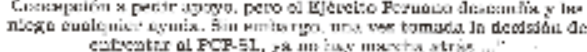

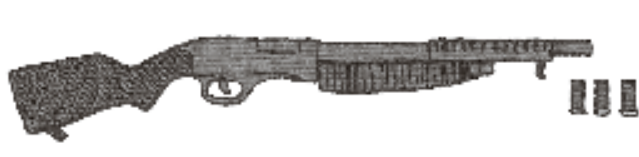

ze verantwoordelijk voor het terugdringen van de PCP-SL, zoals blijkt uit de verwijzing naar de DECA (Defensa Civil Antisubursiva/Antisubversieve Burgerde verchillende onderdelen van het antwie de verij wardj het verbale, het artistieke hn het symbolis Zoals de auteur

Zoals de auteur aangeeft, wil hij in dit werk de vragen niet uitputtend beantwoorden. Het is een inleiding op de materie, een balans van zijn ervaringen tijdens praktische weuzes waarmee hij de lectuur wil vergepraktische keuzes waarmee hij de lectuur wil vergeteert de auteur een tactiek wa bij hij verschillende 
œ discoursen mengt: een educatief discours waarin via woorden en ondersteunende elementen een vereenoudigd op on wis we vebaseerd op een historische basis, waarin de auteur beeldt; en tot slot een officieel discours dat de feiten beeldt, en tot slot een officiel discours dat de feiten

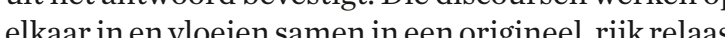

\section{GETUIGENISSEN: STEMMEN EN GEZICHTEN}

Conform de methodologie van de CVR gaat de meeste aandacht uit naar de getuigenissen. Antwoorden op de vijtig viagen betekent dus dat de getuigen in in beeld noeten komen. Cossio tekent het portret van . ${ }^{3}$ ige, wat vor ports plats ver voor het particulis

De keuze voor het portret en de tekstballon zijn cruciaal als je weet welke functie getuigenissen hadde in de onderzoeksteams van de CVR, en ook dat bij wijz an uitzondering openbare zittingen werden gehouden. De tekstballon is de vormelijke vertaling van een gesloten milieu, namelijk de wereld van hetvertrouwejoe en de bekentenis. De getuigen verklaren, doen het relass van hun ervaringen vanuit een ik-standpunt en trachten op hun eigen manier een antwoord te geven op de vraag boven aan de pagina. Vanuit een intieme ho etuige gezien en/orgigenis duidelijk centraal te sta komen getuige en getuigenis duidelijk centraal te staan in he

Getuigenissen vormden een belangrijke bron van informatie voor de CVR, die luisterde naar meer dan kwart Quechua spraken. Na haar oprichting in 200

(3) Elke directe getuige die de lezer toespreekt wordt geïdentificeerd:
zin/haar naam, voornaam en soms ook functie of statuut worden naast het portret vermeld (vgl. de voorbeelden hierbij). (4) De Quechua-titel van de ingekorte versie van het CVR-eindverslag
luidt Hatun Willakuy, wat 'groot verhaal' betekent stuurde de CVR onderzoeksteams uit die het Quemachtig waren; zij verzamelden getuigenissen bij bevolkingsgroepen die bij het conflict betrokken waren en bereid waren te praten. Nadat ze de aparte evallen bestudeerd en bijelkaar sobrachthad, trachtte de CVR te begrijpen wat dit alles betekende in natinaal verband. De individuele getuigenissen hielpen us om tot historische verklaringen te komen en ze droegen bij aan het collectieve waarheidsstreven. Doo haar werk op het terrein bevorderde de CVR dus de ontmoeting tussen twee werelden en wist ze toch de ontmoeting tussen twee werelden en wist ze toch de in het Pera trekkenvan ween antalgroepen. Specifiek het Perme lijve hadden on jorengun veroorde tot zwijen, verger

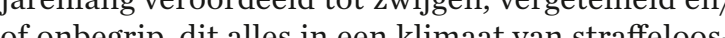
oid Degrip, dit alles in een klinaat van straffeloosheid. De urgentie die normaal gezien uitgaat van een je ziet hoevel tijd ov vigens niet van toepassing, als jeite hoel tijd er verliep tussen de gewelddadige ingen (vijf tot twintig jar). Door die latentieperiode ringen (vijf tot twintig jaar). Door die latentieperiode zijn de ervaringenvan de aparte gemeenschapsleden in zere zomt de feiten feiten. Het persoonlijke getuigenis gaat deel uitmaken den en wordt tevente verleden en wordt een schakel in de ketting waarmee de Die kracht wil Jesús Cossío hier nar vordt gebracht. Vraag 27 Jesús Cossio hier naar voren schuiven. Vraag 27 gaat over de verklaring van twee naamloze bewoners van de selva (tropisch regenwoud). Het Pert dat ze anoniem blijven, is een verwijzing naar de door de CVR a dor de CVR aan het licht gebracht toen ze het aantal slachtoffers telde. We mogen niet vergeten dat in 1980 wijs hadd twee miljoen Peruanen geen identiteitsbewijs hadden en dat, zoals Daniel Dupuy uitlegt, 'een chilfoen Peruanen hun geboortebewijs hadden verloren' (Dupuy 2009, 169) nadat de dorpen tijden. het conflict waren aangevallen. De naamloosheid van de Andesindianen en de gemeenschappen in de selva zou kunnen verklaren waarom de mensen in het westen van het land, onwetend als ze waren van de oorlog schillig reand, zo wenig of zelfs sond it onver-

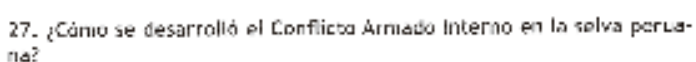

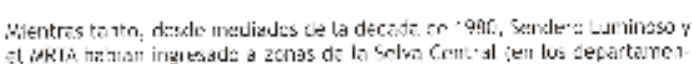

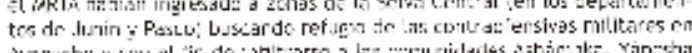

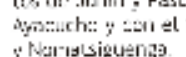

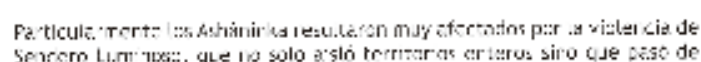

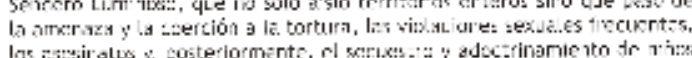

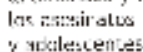

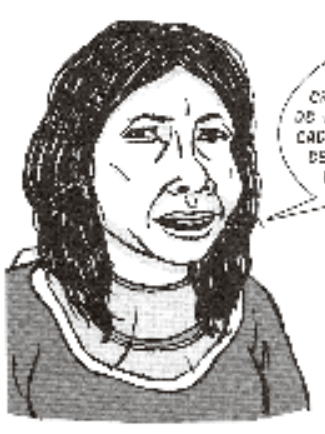

setsetsan or oic
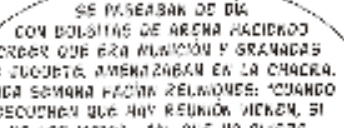

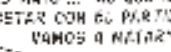
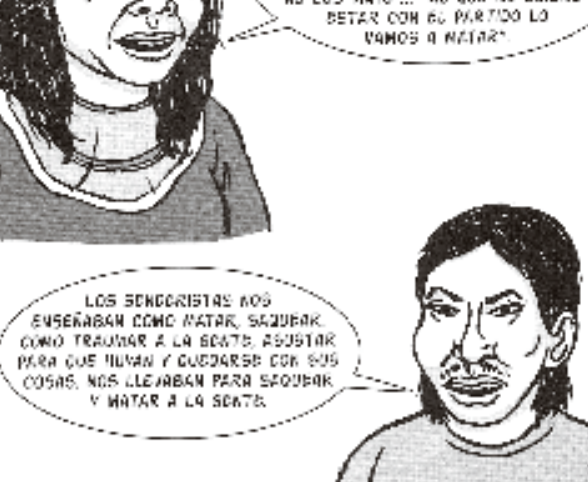

van de andere bleek opnieuw toen de autoriteiten tijdens een verderfelijke polemiek hun twijfels gingen uiten over de schatting die de CVR had gemaakt va het boek vernemen we hoe de PCP-SL deze gemn in choek verne schappen gebruikte voor haar strategie van gewapend kassenstrijd.intimidatie, bedreigng, seksueel geweld, ideologische onderwing tot gew (verker het scholken het schokkende getuigenrelaas. Door de personages bij de orsprolijk bij de oor blijkbaar geen narratieve of emotionele filters gehanteerd, maar uit noodzaak werd wel gebruik gemaakt van taalkundige transcriptie: vertaling van de talen van de Amazonegemeenschappen naar het Spaans of tekstaanpassing voor een optimaal begrip.

Los van deze 'privégetuigenissen' is Peru ook het d dat openbare zittingen (a) worden erkend worden erkend. zittingen betreffende specifieke gevallen (in aanwezigeid van de slachto en zeven openbare zittingen in het hele land. Daaronder burn worden de (vak subalterne) slachtoffers in hun moederda (vich su getuigden, konden ze zich maatschappelijk positioneDaniel Dupuy was de voorno bijiel Dupuy was devoornamste betrachting bij die bijeenkomijk als volwaardige burgers werden erkodat (Dupuy 2009, 165). Het volgende voorbeld (Dupuy 2009, 165). Het volgende voorbeeld gaat ove Haar rafische weergave komt overee met dewer-

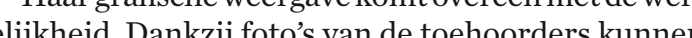
kelijkheid. Dankzij foto's van de toehoorders kunnen we zien hoeveelzorgde auteur besteedde aan de fysieke gelijkenis met de historische persoon, en dan voora voor een publiek en doet het relaas van hich profoo lijke ervaring tijdens de terreuriaren: haar moede lijke ervaring tijdens de terreurjaren: haar moede wens Dankzij het gebruik van gedachtepuntjos en gens. Dankzij het gebruik van gedachtepuntjes en de tastbre is deze verklaring doordrenkt van een nog het feit dat het trauma voortdurend opnieuw wals belefd De rel van de 'infortdur' is opnieuw word vormt de verbinding tussen lazern

(5) Enkele concrete themás: antiterrorismewetgeving, geweld en
misdaden tegen vrouwen, geweld op de universiteit, ballingschap enzovoort. (6) Huanta, Huamanga, Huancayo, Huancavelica, Lima, Tingo María,
Abancay, Trujillo, Chumbivilcas, Cusco, Cajatambo, Pucallpa, Tarapoto Abancay, Trujillo, Chy
Huánuco, Chungui. 
•. en kinderen; hij waagt zijn leven om de stem van rede en waarheid te vertolken. Liz neemt de rol van getuige op zich om licht te werpen op het duistere verleden.

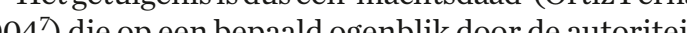
2004) die op een bepaald ogenblik door de autoritejterm word toegestaan, waardoor een nieuwe waarheid was geloochend, genegeerd en zelfs ontkend.

DE ETHISCHE DIMENSIE VAN HET

COLLECTIEVE GEHEUGEN: VERGETELHEID EN

ONVERSCHILLIGHEID OVERWINNEN

Veeleer dan de lezer een verhaal te vertellen laat de auteur herhaaldelijk blijken problemen te willen aankaarten die inherent zijn aan het conflict en die te maken hebben met gezag, schande, racisme, gebre co re revieve aanpak laat toe een helder beetd en. Die reflexieve aanpak lat toe een helder beeld

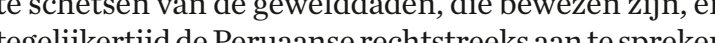
tegelijkertijd de Peruaanse rechtstreeks aan te spreken text mot je de more kwestie wel verbinden consinds de jo de mo inds de kolonisering geldende morele hiêrarchie. De

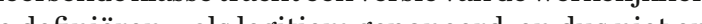
te defnieren - als legitien geponeerd, en dus niet er moreel als je kijkt naar hetgezag dat ervan uitgaat - en klasen, de hassen, die haar noetena a artijdigheid loowar partspraken kom illende uitspraken in verschillende mate al naargelang de sociale organisatie, we hechten meer geloof aan de versie dan aan dis van ondergeschikten of subalternen (zil die vanuit een lagere positie op de sociale pen (zije cie vanuit een lagere positie op de sociale piranide geacht word netie). Want het recht op warber het grotere plaatje). Want het recht op waarheid en lijke wijzan spreken zijn niet in alle culturen op bilkrijgt voorrang. Getuigenissen houden nu intrinsiek (7) In dit essay laat Carolina Ortiz Ferná zien dat getuigenissen een
machthdadad zinj, want ze kunnnen uitgroeien tot een instrument van
dominatie of

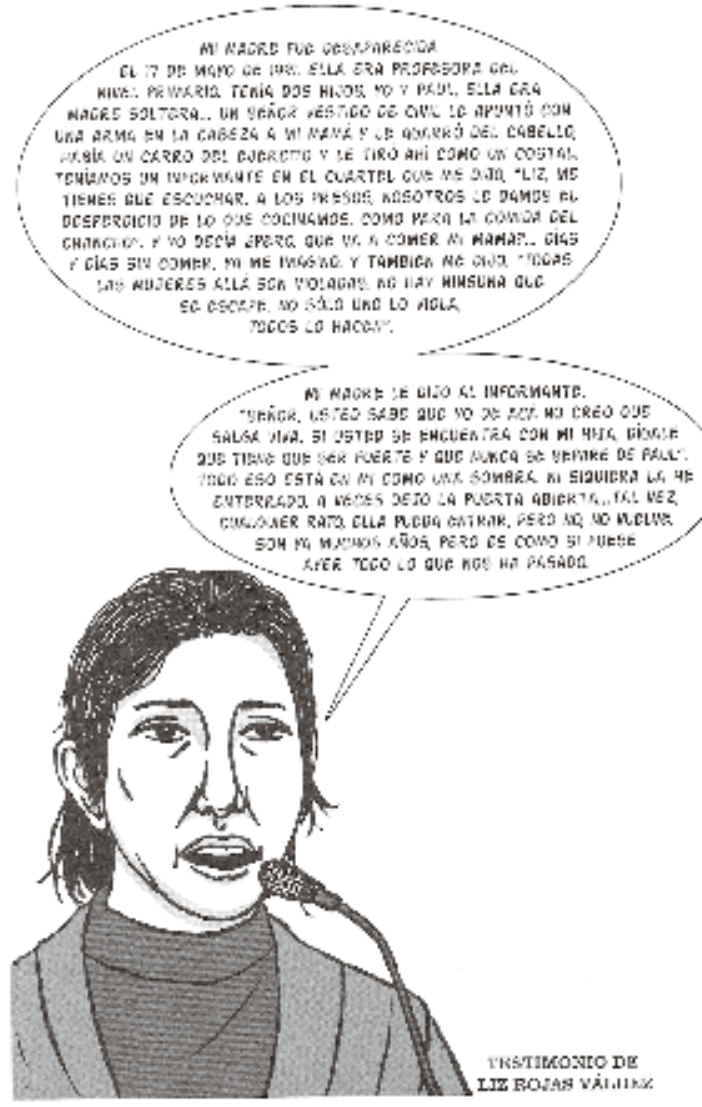

van een blanke vrouw en man (zie tekstballonnen) en het naast hun afbeeldingen geplaatste CVR-vertoos bij wijze van antwoord op/verdediging tegen hun ijgingen. Zo worden hun argumenten als leugen ontmaskerd. Hun aanvallen worden ontkracht via tegenarelijke tionens, rechts is niet representatief voor de De cliteit en het fit dat ze tek the envermogen om rect van een multiculturele sase a een murdent san ergen wa

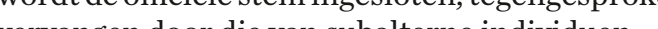
wervangen door dievan subalterne individuen.
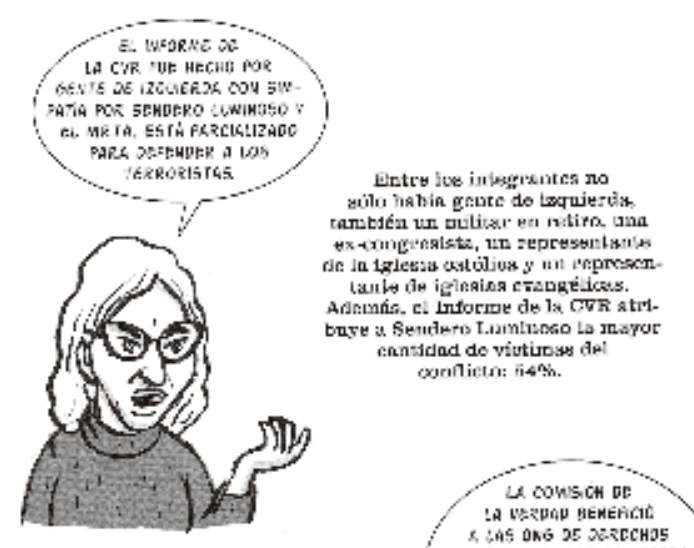

een omkering in van die morele orde: leden van zogeaamd minderwaardige groepen krijgen het woord en zolang hun verklaring duurt, verhuizen ze naar de top van de organisatie en behoren ze tot diegenen die ove kennis beschikken. En al is kennis niet altijd een waarborg voor geloofwaardigheid, toch wordt de officiële waarheid vaak bijgesteld door die getuigenissen. Het gebeurt echter dat, wanneer de 'vertegenwoordigers' van de gevestigde moraal door mediaonthullingen en door de CVR worden aangeklaagd, ze de leugen en straffeloosheid inzetten om hun hachje en sociale positie te redden

In het volgende voorbeeld worden twee vertogen tegenover elkaar gesteld: het oligarchische vertoog
Getuigenissen zijn hier een middel om staatsgeheiGen relaas ten voordele De ne van de 'stench

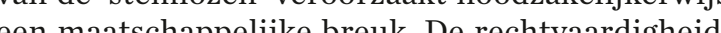
als 'bethe 42), lijkt we pro sociologish probunt vragt Nandini Sundar zich f bep om straffeloosheid en de mythe van de collectieve s. onschuld te rechtvaarigen. De morele plicht van de cen warborg voor moraliteit. De kloof tu niet altijd en woorder vor moraliteit. De kloof tussen feiten ris grafische confontatie. Het getuigenis van Rosa Rojas ring kunn eed vor be ring kunnen we de schaal van lijdensvormen en verantwoordeljkheden opnieuw bekijken. Hoe kan zij de kelf een en wandaden van Fujimori aanhoren als ze (elf een slachtoffer is van de Colina-groep, of rechtpresident wordt vis belijkt in het licht van de president wordt vergoelijkt in het licht van de doo van een onschuldige zoon en het oniting an en ander, van wie het lijden niet lijkt te worden Verderop in het hiluen niet likt te worden erkend. (leider van de Colina-groep), merken we de Rivas (leider van de Colina-groep), merken we de neiging ochter de verplichting die samenga zichte verbergen ach opdracht en het dienen van de bevolking. In dit moralistische vertoog wordt de plicht van de militairen on zich te verdedigen vaak zozeer verantwoord dat ze de erant onter-elkar. over-elkaar-plaatsen van uitspraken een manier on manipulatie- en misleidingsstrategieên te nuanceren en aan het licht te brengen. Het is ook een manier on anter facto gericht op het verdedicen van de 'stem facto gericht op het verdedigen van de 'stemlozen'. Cossio's toolboek is ongetwijfeld een origineel pedagogisch instrument om het over het gewapend dien in schoolboeken zelden of maar vluchtig wordt 


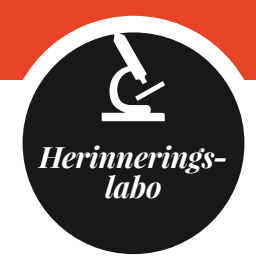

•• aangehaald. ${ }^{8}$ De lezer krijgt essentiële (zij het geen uitputtende) kennis betreffende dit tijdvak aangereikt dankzij de didactische opzet van het werk. Via een meervoudige discursieve aanpak levert het een bijdrage tot de collectieve plicht om niet te vergeten: destemmen en gezichten van de getuigen worden naast die van de beulen geplaatst en dit alles wordt getoetst aan de officiële versie van de CVR, om zo de vinger te leggen op afwijkingen en overeenkomsten. Door zijn visuele enscenering eist de auteur het recht op waar-

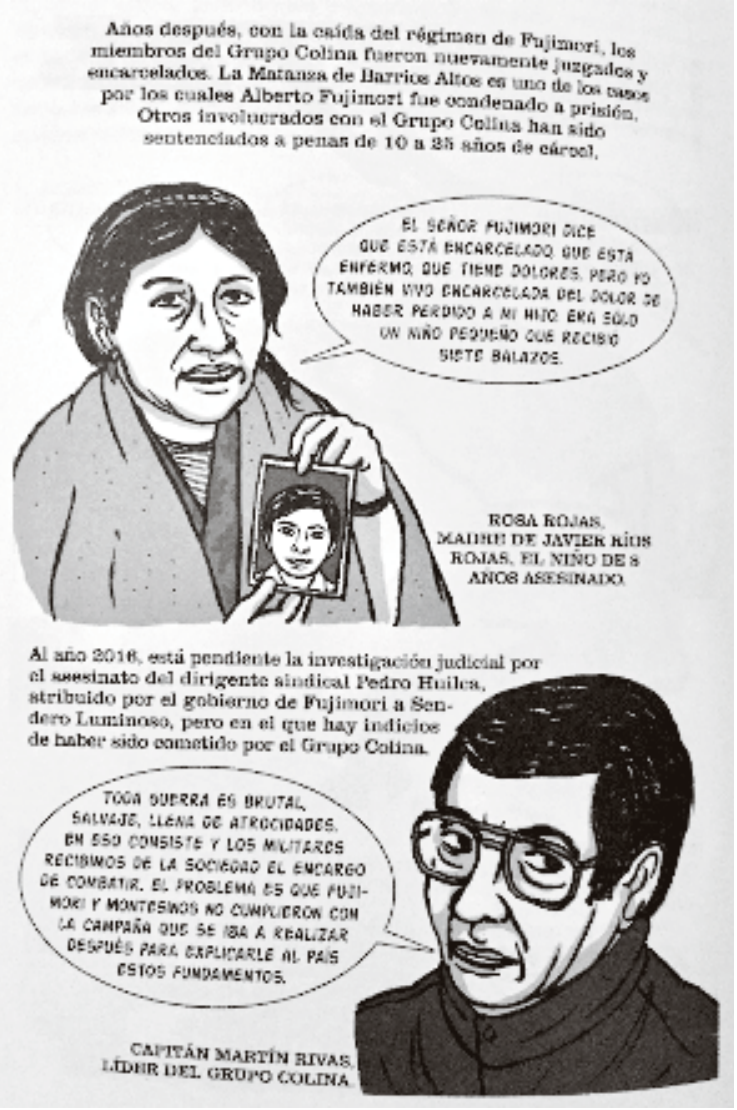

(8) In 2017 wordt het conflict in schoolboeken summier en op een paar bladzijden behandeld. De fundamentele problemen rond corruptie en politiek geweld worden niet aangeraakt. heid op en verwerpt hij de vergetelheid betreffende de 'terreurjaren', twee thema's die als een rode draad door het werk lopen.

\section{Mylène Herry}

Université Toulouse - Jean Jaurès Vertaling uit het Frans: Gorik de Henau

\section{BIBLIOGRAFIE}

- Howard Becker, 'Moraliser le monde? De quel côté sommes-nous?', in Didier Fassin \& Samuel Lézé, La question morale. Une anthologie critique, Parijs: PUF, 2013, 480.

- Tahar Ben Jelloun, Papa, wat is een moslim?, uit het Frans vertaald door Zsuzsó Pennings, Breda: De Geus, 2002.

----, Papa, wat is een vreemdeling?, uit het Frans vertaald door Zsuzsó Pennings, Breda: De Geus, 2006.

----, Le terrorisme expliqué à nos enfants, Parijs: Seuil, 2016 [voorlopig niet vertaald].

- Daniel Dupuy, ¿Dónde están? Terreur et disparitions au Pérou (1980-2000), Le Pré-Saint-Gervais: Le Passager Clandestin, 2009.

- Didier Fassin \& Samuel Lézé, La question morale. Une anthologie critique, Parijs: PUF, 2013.

- Carolina Ortiz Ferná, 'El testimonio ¿un acto de poder? Sobre el proceso de producción e interpretación del testimonio', Investigaciones sociales 8 (13), 245-252, http://sisbib.unmsm.edu.pe/BibVirtualData/publicaciones/ inv_sociales/N13_2004/a13.pdf (geraadpleegd 29 mei 2017).

- Nandini Sundar, 'Tensions pratiques. Culpabilité et réparation', in Didier Fassin \& Samuel Lézé, La question morale. Une anthologie critique, Parijs: PUF, 2013, 411-424.

- Hatun Willakuy, Misereor, Lima, 2008. 